\title{
Identifying Factors Affecting the Sustainability of Water Environment Treatment Public-Private Partnership Projects
}

\author{
Huimin Li $\mathbb{D}^{1,2}$ Qing Xia $\mathbb{D}^{1,},{ }^{1,3}$ Shiping Wen $\mathbb{D}^{4},{ }^{4}$ Lunyan Wang, ${ }^{1,5}$ and Lelin $\mathrm{Lv}^{1,3}$ \\ ${ }^{1}$ School of Water Resources, North China University of Water Resources and Electric Power, Zhengzhou 450046, China \\ ${ }^{2}$ Henan Key Laboratory of Water Environment Simulation and Treatment, Zhengzhou 450045, China \\ ${ }^{3}$ Collaborative Innovation Center of Water Resources Efficient Utilization and Protection Engineering, Zhengzhou 450045, China \\ ${ }^{4}$ School of Economics and Management, Tongji University, Shanghai 200092, China \\ ${ }^{5}$ Academician Workstation of Water Environment Governance and Ecological Restoration, Henan Province, \\ Zhengzhou 450002, China
}

Correspondence should be addressed to Shiping Wen; pp66dd@126.com

Received 18 February 2019; Accepted 9 April 2019; Published 2 May 2019

Guest Editor: Endong Wang

Copyright (c) 2019 Huimin Li et al. This is an open access article distributed under the Creative Commons Attribution License, which permits unrestricted use, distribution, and reproduction in any medium, provided the original work is properly cited.

Sustainability has recently been acknowledged as a crucial issue in infrastructure projects. Developing a model to evaluate project sustainability according to sustainability indicators plays a major role in promoting the sustainable development of water environment treatment public-private partnership (PPP) projects. Traditional sustainability assessments are mostly based on the triple bottom line (economic, social, and environmental) and lack a more integrated indicator system. To connect the research gap, this paper identifies 27 factors that affect the sustainability of water environment treatment PPP projects from five dimensions: economy, society, resources and environment, engineering, and project management using exploratory factor analysis. The fitting degree between the model and original data is verified by confirmatory factor analysis. The results showed that the fitting was successful. This paper makes two contributions: first, it provides a comprehensive sustainability evaluation indicator system from five aspects, laying a foundation for the evaluation of project sustainability. Second, this study defines a methodology to evaluate and rank factors, identifies the indicators that show the most significant impact on project sustainability in the five dimensions, which provide a reliable reference for the public and private sector to take appropriate measures to improve the sustainability level of water environment treatment public-private partnership projects.

\section{Introduction}

With the rapid development of economy and society, the problem of water environment pollution in China increases significantly. The government has been fully responsible for the investment and management of environmental treatment in the past decades, not only leading to notable financial pressure but also challenging the government's management ability. Water environment treatment projects involve social infrastructure projects, such as sewage treatment, ecological restoration, and landscape greening; such projects require professional knowledge, and thus, guaranteeing efficiency while completely depending on the government presents difficulty [1]. Introducing publicprivate partnership (PPP) into water environment treatment has gradually become critical. On the one hand, it can alleviate the burden of public financial shortage and ensure the timely provision of needed infrastructure [2]. On the other hand, a private sector with valuable business opportunities can use innovative technologies and advanced management skills to improve governance efficiency and enhance the effect of water environment treatment $[3,4]$. In recent years, the government has exerted considerable effort to promote the comprehensive improvement of the water environment and conducted numerous water environment treatment PPP projects, as shown in Figure 1.

Since the concept of "sustainable development" was defined in the Brundtland Report in 1987, it has gradually been accepted by organizations and governments worldwide [5]. Sustainable development is defined as development that meets the needs of the present without compromising the ability of future generations to meet their own needs. PPP is 


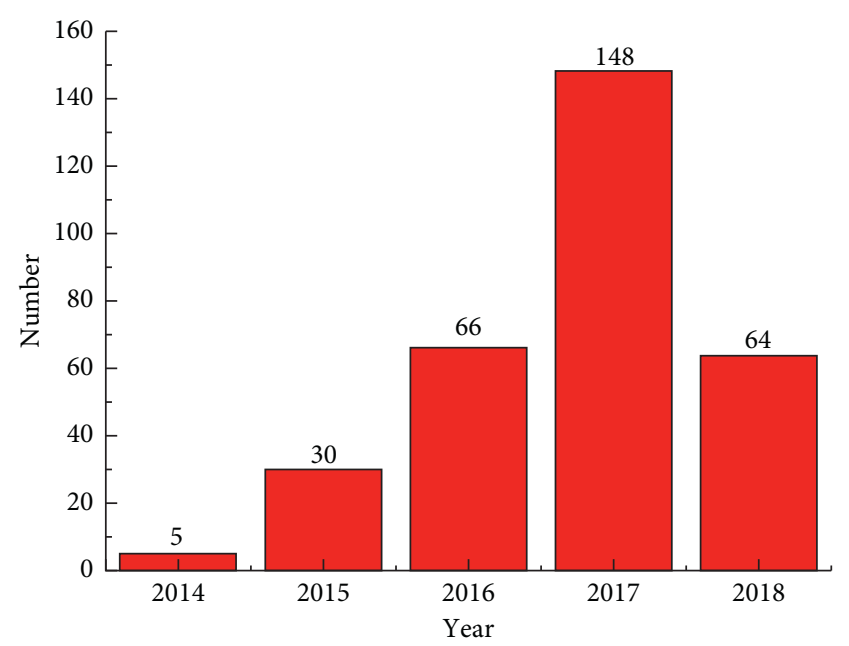

FIgURE 1: The number of water environment treatment PPP projects undertaken in the past five years. Note. The data of this paper are from the PPP center project management database of the Ministry of Finance, and the statistical time is as of October 11, 2018.

sometimes mentioned as a potential method for achieving sustainability goals [6]. Given the financial pressures faced by the government and the increased efficiency provided by the private sector, PPP has become one of the preferred ways for the government to develop infrastructure. However, as the participation of the private sector in PPP projects is profitdriven, it is easy to pay too much attention to the economic target of whether the project is profitable, while ignoring the impact of the project on the environment and society. Second, the private sector emphasizes short-term financial returns on investment, but the sustainability performance of projects can only be achieved from a long-term perspective. Thus, the concept of sustainable development needs to be included in infrastructure projects delivered through PPP; otherwise, the projects would fail [7]. The sustainability of PPP projects should consider two aspects. First, PPP infrastructure projects should be consistent with the level of regional economic development, which means not only meeting the long-term and effective demand of the public but also promoting the sustainable development of society, economy, environment, and resources. Second, the development of the project itself should be sustainable, including aspects such as the durability of the project itself, life-cycle cost, and energy consumption. Therefore, in order to achieve sustainability and promote the healthy development of PPP projects, it is necessary to evaluate their sustainability.

Infrastructure projects have major effects on implementing the principles of sustainable development. Therefore, researchers investigated infrastructure project sustainability from different perspectives. Timmermans and Beroggi [8] studied the sustainability assessment of infrastructure from several aspects, including economic sustainability, social sustainability, technological safety, attractiveness for living, and attractiveness for businesses. Sahely et al. [9] developed a framework that focuses on key interactions and feedback mechanisms between infrastructure and surrounding environmental, economic, and social systems for the sustainability assessment of urban infrastructure systems. Shen et al. [10] introduced key assessment indicators (KAIs) for assessing the sustainability performance of an infrastructure project from three dimensions embodied in sustainable development principles (i.e., economic, environmental, and social). Most research started from the sustainable triple bottom line, economic, social, and environmental aspects and lacked more comprehensive assessment indicators, which constitute an obstacle to effectively assessing the sustainability of infrastructure projects. For example, projects may succeed or fail in terms of how they reach their goals and how they are managed [11]. Achievement of project goals requires efficient project control [12]. Previous studies focused on the environmental aspects of sustainability in project deliverables while giving less attention to sustainable project management during project delivery [13]. Armanios [14] believed that if we are to possess a more complete and holistic view of sustainability, engineering sustainability needs to be considered and discussed more. At present, few investigations are available on the sustainability of PPP infrastructure projects. Hueskes et al. [7] showed that sustainability considerations currently play only a limited role and that social dimensions of sustainability are largely neglected in PPP infrastructure projects.

To connect these gaps, we aim to consider more comprehensive sustainability aspects into the water environment treatment PPP projects. This paper aims to identify the sustainability indicators (economy, society, resources and environment, engineering, and project management) in water environment treatment PPP projects according to previous studies. This paper also ascertains how such factors are identified and measured. Finally, this paper also aims to determine a methodology for evaluating and ranking critical factors of water environment treatment PPP projects. This study constructs a theoretical research framework for sustainability evaluation of water environment treatment public-private partnership projects in a comprehensive and multidimensional way. Moreover, this paper identifies the indicators that show the most significant impact on project sustainability, which provide a useful reference for the public and private sector to take appropriate measures to improve the sustainability level of water environment treatment public-private partnership projects.

The remainder of the paper is organized as follows. Section 2 reviews the sustainability literature on infrastructure projects, $\mathrm{PPP}$, and water management. Section 3 preliminarily constructs the PPP project sustainability evaluation index system from five aspects: economy, society, resources and environment, engineering, and project management sustainability. Section 4 introduces the research methodology. Section 5 presents the data analysis, including exploratory factor analysis, confirmatory factor analysis, and calculation of indicator weights. Section 6 discusses the factors influencing water environment treatment PPP projects. Finally, Section 7 describes the conclusions, practical implications, limitations, and future work of this study.

\section{Literature Review}

2.1. Sustainability of Infrastructure Projects. Sustainability is commonly understood through its three components, which 
are often referred to as the triple bottom line. In infrastructure projects, the sustainability of deliverables and delivery processes are both crucial as they can have remarkable social and environmental impacts [13].

Infrastructure is the foundation of social and economic development, hence resulting in the heavy infrastructure investment in developing countries. From 1970 to 2005, more than $30 \%$ of the World Bank's investment served to implement various types of infrastructure in developing countries [10]. In general, infrastructure projects provide a natural monopoly, externality, and indirect benefits. Therefore, evaluating their sustainability is necessary [15].

Researchers conducted sustainable research on infrastructure projects from different perspectives. Shen et al. [16] suggested that to achieve better sustainability, interests, powers, and responsibilities should be divided among the project parties within the concession term of the infrastructure project. Dasgupta and Tam [17] synthesized the sustainability indicators of civil infrastructure projects by using a multiobjective decision approach to facilitate the choice of practical alternatives for better sustainability performance. Ugwu et al. [18] used the weighted-sum model technique in multicriteria decision analysis (MCDA) and the additive utility model in the analytical hierarchical process (AHP) to develop a multicriterion decision-making model for sustainability appraisal in infrastructure projects. Timmermans and Beroggi [8] argued that economic sustainability, social sustainability, technological safety, attractiveness for living, and attractiveness for businesses should be considered when assessing infrastructure project sustainability. Shen et al. [10] believed that project sustainability assessment indicators in previous studies were fragmental and that a complete assessment system was lacking. Therefore, they introduced KAIs for assessing the sustainability performance of an infrastructure project according to the triple bottom line. Kivilä et al. [13] argued that less attention has been directed at sustainable project management during project delivery and indicated that sustainable project management is implemented using not only indicators but also a holistic control package, in which control mechanisms are used differently for various sustainability dimensions. Internal project control is complemented with sustainable project governance, which links the project to external stakeholders and regulations. Amiril et al. [19] explored the relationship between sustainability factors and the performance of transportation infrastructure projects and identified the sustainability factors involved in environmental, economic, social, engineering/resource utilization, and project administration issues. Their findings will promote the implementation of sustainability strategies and provide theoretical support and reference for the study of the sustainability of water environment treatment projects.

In summary, sustainability has received wide attention in infrastructure projects. Previous studies examined the sustainability of infrastructure from the triple bottom line principle. Recently, several researchers have begun to study the sustainability of infrastructure from other aspects, e.g., project management sustainability and engineering sustainability. For an infrastructure project, not only its impact on the outside environment (economic, social, and environmental) but also the sustainability of the engineering itself and project management should be paid attention to. Engineering sustainability is the foundation for water environment treatment PPP projects. Project management sustainability is the core meaning to guarantee and promote the sustainable development of economy, society and environment.

2.2. Sustainability of PPP Projects. PPP is a procurement approach where the public and private sectors join forces to deliver a public service or facility. In this arrangement, normally, the public and private sectors will contribute their expertise and resources to the project and share the involved risks $[20,21]$. PPP is widely used in infrastructure construction and public services because of its effective financing capacity, which can help mitigate the risk of local government debt [22].

With the global application of PPP, more related studies have been conducted, such as those on PPP risk management [23], key success factors [24], governance [7], and sustainable development $[7,25,26]$.

PPP has been adopted as the preferred route for the development of infrastructure projects by both developing and developed countries. However, Koppenjan and Enserink [27] argued that private sector involvement in infrastructure leads not necessarily to sustainable development as the private sector is primarily concerned with short-term financial returns on investment, and the sustainability performance of projects can only be achieved from a long-term perspective. Ye and Deng [28] proposed four partnership characteristics, including maintaining the consistency of objectives, long-term cooperation, equal coordination, and benefit-risk sharing, among the three stakeholders, namely, the government sector, the private sector, and the public sector; moreover, the authors developed a method to realize the sustainability of PPP infrastructure projects. Shen et al. [25] believed in the differing expectations of the public and private sectors; allocation of investment between these stakeholders poses a significant impact on the sustainable performance of projects. The sustainability performancebased evaluation model (SPbEM) was developed to assess the level of sustainability performance of PPP projects. Patil et al. [21] proposed the sustainability evaluation principle of PPP projects based on stakeholder participation and empowerment, institutional capacity, efficient project implementation, socioecological compatibility, resource utilization efficiency and maintenance, value for money, quality of life, affordability, and compensation. Hueskes et al. [7] observed that the social dimensions of sustainability were largely neglected due to the difficulties encountered in formulating measurable social sustainability criteria. However, a "strong" sustainability perspective is inherently incompatible with the contractual PPP project structure, thus requiring measurable and enforceable performance indicators. Such incompatibility is a major challenge for the sustainability evaluation for PPP projects. 
There are many studies on sustainability in the field of infrastructure, but few focused on the PPP domain, as PPP projects different from traditional investment models, involve many stakeholders, and include complex management structures. Moreover, given its profit-driven nature, the private sector only pays attention to short-term economic benefits and ignores the long-term impact on the economy, society, and environment, thus preventing the realization of sustainable development goals. Therefore, studying the sustainability of PPP projects is valuable.

2.3. Sustainability of Water Management. An increasing number of developing countries are faced with water shortages, for reasons that include the scarcity of natural water resources, population growth, high standards of living, and lack of well-developed supply infrastructure. Water sustainability is essential for humans to live in a healthy manner while maintaining the natural environment [29]. Water also plays a fundamental role in the security of food and energy and in economic growth and poverty reduction. Water shortages, if not met in a timely and sustainable manner, will inevitably result in serious adverse effects on socioeconomic and commercial development [30]. Moreover, for the past 60 years, rapid economic development and urban population growth have outpaced environmental infrastructure in urban cities around the world. Cities lack sewer networks. Uncontained raw sewer flows into water bodies, ultimately contaminating the environment. Similarly, sewage pollution threatens human health and wildlife in different regions around the world. This increase in environmental pollution underscores the need for effective environmental resource management [31].

A number of researchers have investigated water sustainability. Elnaboulsi [31] believed that sustainable development of public wastewater utilities can be achieved by promoting full-cost pricing and considering external costs from wastewater services. Reduction in drinking water consumption, also through the reuse and recycling of unconventional sources of water, has been identified as one of the goals of sustainable development. Therefore, Zanni et al. [32] evaluated and compared the environmental impacts attributable to the use of water supply sources (such as rainwater harvesting and graywater recycling), which present alternatives to the traditional one, through the combined use of life-cycle assessment and a hydrological model. Pellicer-Martínez and Martínez-Paz [33] proposed the use of water footprint indicator to assess environmental sustainability in water resource management at the river basin level. Nuong et al. [34] used the AHP approach to evaluate the social sustainability of Hanoi's groundwater resources from three aspects: quantity, quality, and management of water.

In summary, most studies on water sustainability focus on one aspect: economy, society, or environment. Furthermore, many investigations were conducted on the sustainability of water resources but few on water pollution and water environment treatment. A healthy water environment is the premise and foundation for the sustainable development of cities and towns. It is an important factor to ensuring the harmonious development of human and nature, human and society, and the city, economy, and environment, aside from being an objective requirement for the healthy development of China's urbanization. At present, water environment treatment PPP projects have become an important part of China's public infrastructure construction projects. Therefore, it is necessary for the government to evaluate the sustainability of water environment treatment PPP projects from comprehensive dimensions.

A review of the current literature indicates that sustainability has been widely researched in infrastructure projects and water resources, but little research has been done on PPP projects, water pollution, and water environment treatment. Furthermore, most research started from the sustainable triple bottom line and lacked more comprehensive assessment indicators. To connect these gaps, this paper provides a comprehensive sustainability evaluation indicator system of water environment treatment PPP projects from the economic, social, resource and environment, engineering, and project management aspects through structural equation modeling (SEM). This approach will further lead researchers to identify factors that affect the sustainability of other industry sector PPP projects.

\section{Establishment of Sustainability Evaluation Indicator System of Water Environment Treatment PPP Projects}

In practice, sustainability is represented in assessment processes through the use of certain sustainability indicators, where indicators should provide a simplified but still sufficient interpretation of sustainability. The development of sustainability indicators has emerged as a field of study in its own right, albeit one has been described as rather confusing and nonconsensual [35].

Most researchers have proposed various methods and evaluation index systems to assess the sustainability of infrastructure projects from the perspective of the sustainable triple bottom line. In this paper, we will construct a sustainability evaluation indicator system of the water environmental treatment PPP project from the five aspects of economic, social, resource and environment, engineering, and project management (Figure 2).

3.1. Economic Sustainability. Economic sustainability not only means that PPP projects should bring long-term, stable, and reasonable investment returns to the project itself [36] but also the impact on the local economy and development. Long-term in this description means that the private sector should effectively integrate the construction stage with the operation and maintenance stage to reduce the life-cycle cost and avoid the situation wherein contractors only consider short-term construction profits and ignore long-term operation and maintenance efficiency. Stability requires local governments to possess the capability and credit to continue paying. A common problem is that the projects implemented by the current local government leader are not 


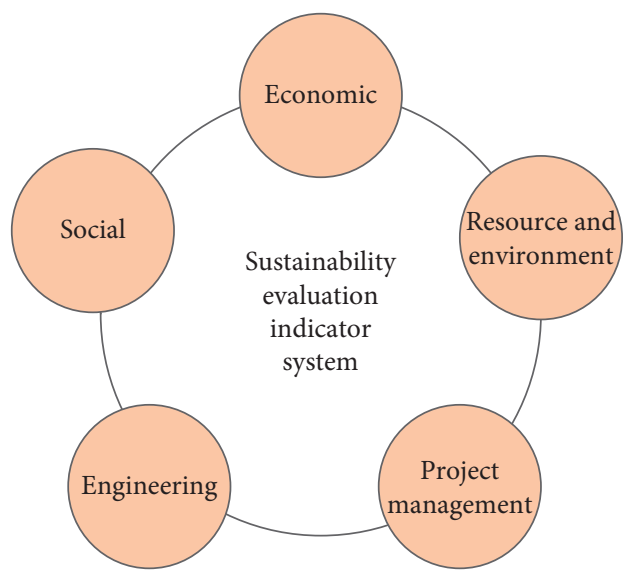

FIgURE 2: The sustainability evaluation indicator system of water environmental treatment PPP projects.

recognized by the next leader, thereby causing the government to break the contract. Reasonable means that, on the one hand, the profit rate of the project should be able to attract the private sector, and on the other hand, the project should not generate excessive profits. Balancing the relationship between the social and economic aspects of PPP projects is necessary. Besides the economic sustainability of the project itself, a water environmental treatment PPP project would also increase the land value around the project and promote local economic development.

3.2. Social Sustainability. Among the three main pillars of the sustainability concept (including environmental, social, and economic pillars) [37], the social criterion has specifically received less consideration than the economic and environmental criteria [38], because this concept is typically difficult to define and quantify. No specific definition of social sustainability exists. Thus, each study defines the concept according to its own specific viewpoints. In this paper, social sustainability refers to providing the public with satisfactory goods and services through measures that enhance the social development potential of the project area, provide employment opportunities for local people, and improve the quality of life.

\subsection{Resource and Environment Sustainability. Resource and} environmental sustainability mean giving a better world to the future generation and protecting ecological balance and natural systems from destruction [39]. People require extensive infrastructure to sustain their lives. During infrastructure construction, operation, and maintenance, environmental problems will arise, and they can be attributed to the consumption of nonrenewable resources and the decrease in biological diversity [40]. Therefore, adopting green building technology and using renewable energy during infrastructure construction are necessary to achieve energy conservation, emission reduction, and environmental protection. In addition, for water environment treatment projects, the sustainability of resources and the environment can be improved by reducing pollutant discharge, improving sewage treatment rate, and comprehensive utilization of water resources.

3.4. Engineering Sustainability. The definition of PPP project sustainability implies that PPP infrastructure projects should not only promote the sustainable development of society, economy, resources, and environment but also require the sustainable development of the project itself, specifically, its durability (i.e., engineering quality), operation, and maintenance capability and the sustainability of the technology itself.

Various governments around the world have spent considerably more money on new infrastructure and less on infrastructure maintenance. For example, reports of gas pipe leak or explosion, bridge collapse, or supply water pollution are common in China. Such accidents are caused by the insufficient maintenance of infrastructure. Poorly maintained infrastructure projects have led to various social and environmental problems. Therefore, to achieve healthy project development, the operation and maintenance capacity of projects should be improved, and attention on the sustainability of the engineering should be strengthened.

3.5. Project Management Sustainability. Project management sustainability refers to ensuring profitable, fair, transparent, safe, ethical, and environmentally friendly project delivery, which aims at a project deliverable that is socially and environmentally acceptable throughout its life cycle [41].

Carvalho [42] indicated the importance of soft skills, such as those related to communication and stakeholder management, in project management. Scott-Young and Samson [43] also pointed out that personnel management factors contribute more to the success of a project than technical factors. For water environment treatment PPP projects, professional technicians and managers are needed. Moreover, such projects involve a long operation, a wide range, and numerous stakeholders. Thus, the organization structure should change with different concessionary stages. Furthermore, a stable project organization structure and effective communication are needed in the operation period to ensure the continuous and healthy operation of the project.

In summary, this paper uses literature review and expert interviews to identify the sustainability evaluation indicators of water environment treatment PPP projects from five aspects: economic, social, resource and environment, engineering, and project management. Table 1 shows the specific indicators.

\section{Research Method}

4.1. Questionnaire Survey. This research was conducted using a combination of structured interviews with industry professionals, a review of sustainability literature, and questionnaire-based survey for indicator validation. The survey was conducted over a two-month period from 1 August 2018 to 1 October 2018. A total of 200 questionnaires 
TABle 1: Sustainable development indicators.

\begin{tabular}{|c|c|c|c|}
\hline Dimension & Codes & Indicator & Sources \\
\hline \multirow{6}{*}{ Economic sustainability (Eco) } & Ecol & Internal return ratio (IRR) & {$[10,44]$} \\
\hline & Eco2 & Land value-added benefit around the project & {$[10,39,45]$ expert interviews } \\
\hline & Eco3 & Life-cycle cost & {$[10,18,39,46-48]$} \\
\hline & Eco4 & Sustainable cash flow & {$[10,45]$} \\
\hline & Eco5 & Effects on local economy and development & {$[10,45,49]$} \\
\hline & Eco6 & Fiscal pressures of government & {$[50,51]$ expert interviews } \\
\hline \multirow{6}{*}{ Social sustainability (Soc) } & Soc1 & Public satisfaction & $\begin{array}{c}{[13,46-48,52] \text { expert }} \\
\text { interviews }\end{array}$ \\
\hline & Soc2 & Provision of employment opportunities & {$[10,39,45,53]$} \\
\hline & Soc3 & Potential impact on social development & {$[10,45,54]$} \\
\hline & Soc4 & Trust between public and government & {$[55,56]$} \\
\hline & Soc5 & Provision of ancillary infrastructure to local area & {$[10,45,47,48]$} \\
\hline & Soc6 & $\begin{array}{l}\text { Improvement of the cognition level of the public } \\
\text { regarding sustainable development }\end{array}$ & {$[45,57,58]$} \\
\hline \multirow{9}{*}{$\begin{array}{l}\text { Resource and environment sustainability } \\
\text { (Res) }\end{array}$} & Res1 & Effect on water quality & {$[10,45]$} \\
\hline & Res2 & Reduction of pollutant discharge & {$[59,60]$ expert interviews } \\
\hline & Res3 & $\begin{array}{l}\text { Energy efficiency (e.g., reduction of energy } \\
\text { consumption and use of renewable energy }\end{array}$ & {$[10,18,45,61]$} \\
\hline & & resources) & \\
\hline & Res4 & Biodiversity protection & {$[10,39,46]$} \\
\hline & Res5 & Protection for landscape and historical sites & {$[10,39,46,61]$} \\
\hline & Res6 & Sewage treatment rate & {$[62,63]$ expert interviews } \\
\hline & Res7 & Comprehensive utilization of water resources & {$[46,64]$} \\
\hline & Res8 & Use of innovative materials & {$[10,18,39,46,61,65]$} \\
\hline \multirow{10}{*}{ Engineering sustainability (Eng) } & Eng1 & $\begin{array}{c}\text { Completeness of supporting facilities for the } \\
\text { project }\end{array}$ & [66] expert interviews \\
\hline & Eng2 & Renewal of project facilities & {$[9,13]$} \\
\hline & Eng3 & Construction quality & [61] \\
\hline & Eng4 & Control of pollution sources & {$[59,60]$} \\
\hline & Eng5 & Adoption of advanced engineering technology & {$[9,44]$} \\
\hline & Eng6 & Project quality during operation & {$[52]$} \\
\hline & Eng7 & Sustainability of the technology itself & {$[52,67]$ expert interviews } \\
\hline & Eng8 & Capabilities of operation and maintenance & {$[9,64]$} \\
\hline & Eng9 & Utilization of construction waste & {$[9,39,46-48,61]$} \\
\hline & Eng10 & Waste recycling and reuse & {$[39,46,57]$} \\
\hline \multirow{6}{*}{ Project management sustainability (Pro) } & Pro1 & Organization structure & {$[25,47]$} \\
\hline & Pro2 & $\begin{array}{l}\text { Continual improvement of the operation } \\
\text { management system }\end{array}$ & {$[52,67]$} \\
\hline & Pro3 & Competence and skills of the project team & {$[47,68]$} \\
\hline & Pro4 & Contractual arrangements & {$[13,25,44,61]$} \\
\hline & Pro5 & $\begin{array}{c}\text { Establishment of the PPP contract renegotiation } \\
\text { mechanism }\end{array}$ & [25] expert interviews \\
\hline & Pro6 & (Good) relationship with stakeholders & {$[47]$} \\
\hline
\end{tabular}

were distributed to experts and scholars in the fields of water environment treatment, PPP, project management, and sustainable development, as well as to employees participating in water environment treatment PPP projects. The questionnaire comprised three parts. The first section includes the questionnaire description, which introduces the purpose and content of the survey. The second section involves the basic personal information of the respondents, including the type of organization, the number of projects involved, and work experience. The third section focuses on assessing the importance of the proposed indicators affecting project sustainability, including the aspects of economy, society, resources and environment, engineering, and project management. This section asked respondents to rank each indicator from 1 to 5 to determine their importance in assessing project sustainability. This ranking translates as follows on the Likert scale: 1 = negligible, 2 = unimportant, $3=$ average, $4=$ important, and $5=$ most important.

To validate the questionnaire prior to the survey, a pilot study was also conducted; it involved 30 respondents with more than three PPP projects on water environment treatment. Although minor changes were made in the sentence structure of the final questionnaire, the overall findings of the pilot study indicated the reliability and validity of the questionnaire used for data collection.

4.2. Data Collection. A total of 124 valid questionnaires were collected, with a response rate of approximately $62 \%$. Most respondents (39.5\%) came from research institutions, $17.7 \%$ 
from investment companies, and $11.3 \%$ from government agency. Furthermore, according to the number of PPP projects involved in water environmental treatment, most respondents $(65.3 \%)$ have participated in 1-2 specific projects, followed by those with $3-5$ projects $(19.4 \%)$ and more than 6 projects (10.5\%). Overall, $95.2 \%$ of respondents have participated in related projects. In terms of work experience, most respondents (63.7\%) reported 3-5 years of work experience, $16.9 \%$ claimed 6-10 years, $4.0 \%$ declared 11 15 years, and only $15.3 \%$ professed less than 2 years of work experience. To sum up, the respondents possessed certain work experience, ensuring the effectiveness of the survey results. Table 2 summarizes the demographic information of the respondents.

4.3. Analytical Strategies. The emergence and development of SEM have been regarded an important statistical development in social sciences in recent decades, and this multivariate analysis method has been widely applied in theoretical explorations and empirical validations in various disciplines $[69,70]$. Compared with other statistical tools, such as factor analysis and multivariate regression, SEM performs the factor analysis and path analysis simultaneously [71]. Structural equation models include measurement models and structural models. Factor analysis is the analysis method corresponding to the measurement model, and that corresponding to the structural model is path analysis. Regarding the discussion of the sample size during SEM analysis, although the sample size of most studies is more than 200, Lomax [72] and Loehlin [73] believe that in SEM analysis, if the sample size is not more than 200, there should be at least 100 . The number of samples is 124 in this paper, greater than 100 , which can be analyzed by SEM.

In this paper, factor analysis was used to analyze the collected data. In the process, two-stage procedures recommended by Anderson and Gerbing [74] were followed. In the first stage, exploratory factor analysis was used to define the correlation between variables in samples and a provided set of factors. EFA helps to develop factors for a measurement model through identification of data patterns, determination of the relationship among patterns, and data reduction. Then, the fitting degree of the model and original data was measured by confirmatory factor analysis.

\section{Data Analysis and Results}

5.1. Common-Method Variance Bias Test. In order to determine the possible presence of common-method variance bias among variables, this study employs Harman [75] onefactor test. We observed the guidelines and approach of Podsakoff et al. [76] for conducting Harman one-factor test. For this purpose, all items of the measurement scale were entered into a principal component analysis with varimax rotation, so that any signs of single factor could be identified from factor analysis. The results extracted five different factors from 36 items of measurement constructs and rotation converged in 7 iterations. On the base of these results,
TABLE 2: The demographic information of the respondents.

\begin{tabular}{lccc}
\hline $\begin{array}{l}\text { Demographic } \\
\text { categories }\end{array}$ & Category & Frequency & Percentage \\
\hline & Research institution & 49 & 39.5 \\
& $\begin{array}{c}\text { Design company } \\
\text { Construction }\end{array}$ & 7 & 5.6 \\
Type of & organization & 10 & 8.1 \\
organization & Investment company & 22 & 17.7 \\
& Government agency & 14 & 11.3 \\
& Consultancy & 12 & 9.7 \\
& Others & 10 & 8.1 \\
Number of & 0 & 6 & 4.8 \\
projects & $1-2$ & 81 & 65.3 \\
involved & $3-5$ & 24 & 19.4 \\
& $\geq 6$ & 13 & 10.5 \\
Work & $\leq 2$ & 19 & 15.3 \\
experience & $3-5$ & 79 & 63.7 \\
& $6-10$ & 21 & 16.9 \\
\hline
\end{tabular}

it is determined that this study do not have any problem of common-method variance bias.

5.2. Nonresponse Bias Test. Beuckelaer and Wagner [77] believe that researchers risk losing statistical power in their findings when using small sample survey research, so it is necessary to "test for the possibility of nonresponse bias, and reflect on reasons as to why the sample is so small." This study employs extrapolation method, for testing nonresponse bias. Extrapolation method is most commonly used technique which involves comparison of early and late respondents for possible difference in demographics and mean values of other key constructs [78]. For this purpose, an independent sample $t$-test was performed for comparing the responses of first 50 and last 50 questionnaires. Findings of the independent sample $t$-test revealed that there was no significant 0.05 level difference in the mean values of both groups (i.e., first 50 respondents vs. last 50 respondents). Thus, on the base of the findings of the independent sample $t$-test, it was concluded that there was no substantial difference in the responses of both groups; hence, nonresponse bias is not a problem for this study.

5.3. Exploratory Factor Analysis (EFA). Before factor analysis, Kaiser-Meyer-Olkin (KMO) sample measure and the Bartlett sphere test were first performed to verify whether the indicators were suitable for factor analysis. The test results are shown in Table 3. The results of the KMO measure of sample adequacy and Bartlett's test of sphericity of the entire variables considered in the investigation revealed a $\mathrm{KMO}$ value of 0.865 , which is $>0.7$ and is satisfactory. The value of Bartlett's test of sphericity is 0.000 , which is $<0.05$ and is significant at the $95.0 \%$ confidence level, indicating that the results were satisfactory for further analysis.

IBM SPSS Statistics 22.0 [79] was used to perform EFA on the sample data. To reduce the multicollinearity between the indicators and delete factors with minimal influence, EFA was utilized to reduce the dimensions. In this paper, 
TABLE 3: Test values of KMO and Bartlett.

\begin{tabular}{cccc}
\hline \multirow{2}{*}{ KMO } & \multicolumn{3}{c}{ Bartlett's test of sphericity } \\
& $\chi^{2}$ & $d f$ & Significant level \\
\hline 0.865 & 1631.411 & 351 & 0.000 \\
\hline
\end{tabular}

principal component extraction and orthogonal rotation with Kaiser standardization were adopted to extract eigenvalues greater than 1 . Table 4 shows the rotated component matrix which converged in seven iterations. Bold values denote loading for items, which are above the recommended value of 0.5. The overall Cronbach's alpha $(\alpha)$ of the questionnaire is 0.942; Cronbach's alpha values for each dimension are shown in Table 5. Cronbach's alpha for each factor exceeds the recommended 0.70 level, thereby indicating sufficient reliability [80]. The factors identified for each dimension are described as follows.

Factors affecting economic sustainability include internal return ratio (IRR) (Eco1), land value-added benefit around the project (Eco2), life-cycle cost (Eco3), sustainable cash flow (Eco4), and fiscal pressures of government (Eco6).

Factors affecting social sustainability include public satisfaction (Sco1), provision of employment opportunities (Sco2), and the potential impact on social development (Soc3).

Factors affecting social sustainability comprise effect on water quality (Res1), reduction of pollutant discharge (Res2), energy efficiency (e.g., reduction of energy consumption and use of renewable energy resources) (Res3), protection for landscape and historical sites (Res5), sewage treatment rate (Res6), comprehensive utilization of water resources (Res7), and use of innovative materials (Res8).

Factors affecting resource and environment sustainability include the completeness of supporting facilities for the project (Eng1), renewal of project facilities (Eng2), construction quality (Eng3), control of pollution sources (Eng4), adoption of advanced engineering technology (Eng5), sustainability of the technology itself (Eng7), capabilities of operation and maintenance (Eng8), utilization of construction waste (Eng9), and waste recycling and reuse (Eng10).

Factors affecting resource and environment sustainability include organization structure (Pro1), continual improvement of the operation management system (Pro2), and competence and skills of the project team (Pro3).

5.4. Confirmatory Factor Analysis (CFA). CFA was performed using IBM AMOS version 22.0 [79] to test the validity of the measurement model. The measurement model met Bollen's criteria [81]; that is, each latent variable should feature at least two indicators, and each observed variable is determined by one latent variable. Calculation revealed that the initial model cannot fully meet the criteria of goodnessof-fit (GOF) model. Specifically, the goodness-of-fit index (GFI) was equal to 0.765 , which is less than the recommended level of 0.9 , the adjusted goodness-of-fit index (AGFI) was equal to 0.718 , which is less than the recommended level of 0.8 , and root mean square error of
TABLE 4: Measures of the rotated component matrix.

\begin{tabular}{lccccc}
\hline Item & & \multicolumn{5}{c}{ Component } & \\
& 1 & 2 & 3 & 4 & 5 \\
\hline Eco1 & 0.006 & -0.066 & $\mathbf{0 . 6 6 8}$ & 0.243 & 0.200 \\
Eco2 & -0.005 & 0.299 & $\mathbf{0 . 5 7 0}$ & -0.097 & 0.127 \\
Eco3 & 0.170 & 0.236 & $\mathbf{0 . 6 9 3}$ & -0.019 & 0.088 \\
Eco4 & 0.180 & -0.012 & $\mathbf{0 . 7 5 8}$ & 0.042 & -0.005 \\
Eco5 & 0.071 & 0.039 & 0.385 & 0.266 & -0.138 \\
Eco6 & 0.093 & 0.072 & $\mathbf{0 . 5 7 5}$ & 0.370 & -0.245 \\
Soc1 & 0.201 & 0.504 & 0.026 & 0.235 & $\mathbf{0 . 5 6 9}$ \\
Soc2 & 0.034 & 0.266 & 0.050 & 0.218 & $\mathbf{0 . 6 7 0}$ \\
Soc3 & 0.274 & -0.014 & 0.355 & 0.003 & $\mathbf{0 . 5 8 9}$ \\
Soc4 & 0.228 & 0.046 & 0.090 & 0.209 & 0.473 \\
Soc5 & 0.162 & 0.038 & 0.218 & 0.048 & 0.481 \\
Soc6 & 0.157 & 0.049 & 0.375 & 0.178 & 0.371 \\
Res1 & 0.245 & $\mathbf{0 . 7 1 9}$ & -0.008 & 0.187 & 0.240 \\
Res2 & 0.273 & $\mathbf{0 . 7 6 1}$ & 0.218 & -0.026 & 0.135 \\
Res3 & 0.388 & $\mathbf{0 . 5 7 7}$ & 0.088 & 0.283 & 0.103 \\
Res4 & 0.459 & 0.373 & 0.346 & 0.092 & -0.002 \\
Res5 & 0.132 & $\mathbf{0 . 5 5 4}$ & 0.125 & 0.239 & 0.073 \\
Res6 & 0.357 & $\mathbf{0 . 5 7 1}$ & -0.039 & 0.123 & 0.209 \\
Res7 & 0.312 & $\mathbf{0 . 5 6 8}$ & 0.245 & 0.250 & -0.369 \\
Res8 & 0.168 & $\mathbf{0 . 7 5 5}$ & 0.092 & 0.184 & -0.023 \\
Eng1 & $\mathbf{0 . 6 6 7}$ & 0.293 & 0.147 & 0.107 & 0.200 \\
Eng2 & $\mathbf{0 . 6 5 5}$ & 0.245 & 0.134 & 0.219 & 0.159 \\
Eng3 & $\mathbf{0 . 6 4 9}$ & 0.184 & 0.170 & 0.272 & -0.111 \\
Eng4 & $\mathbf{0 . 5 5 1}$ & 0.085 & 0.259 & 0.391 & 0.088 \\
Eng5 & $\mathbf{0 . 5 4 2}$ & 0.082 & 0.062 & 0.330 & 0.264 \\
Eng6 & 0.403 & 0.096 & 0.367 & 0.067 & 0.309 \\
Eng7 & $\mathbf{0 . 7 2 0}$ & 0.183 & 0.067 & 0.283 & -0.141 \\
Eng8 & $\mathbf{0 . 7 2 4}$ & 0.221 & 0.119 & -0.069 & 0.178 \\
Eng9 & $\mathbf{0 . 7 8 1}$ & 0.162 & -0.033 & -0.090 & 0.062 \\
Eng10 & $\mathbf{0 . 6 9 4}$ & 0.235 & 0.047 & 0.108 & 0.010 \\
Pro1 & 0.230 & 0.197 & 0.168 & $\mathbf{0 . 7 6 2}$ & 0.206 \\
Pro2 & 0.158 & 0.368 & 0.089 & $\mathbf{0 . 6 3 3}$ & -0.053 \\
Pro3 & 0.175 & 0.267 & -0.004 & $\mathbf{0 . 7 3 6}$ & 0.225 \\
Pro4 & 0.129 & 0.178 & 0.059 & 0.401 & 0.212 \\
Pro5 & 0.251 & 0.019 & 0.017 & 0.354 & 0.278 \\
Pro6 & -0.027 & 0.311 & -1.122 & 0.467 & 0.103 \\
\hline & & & & &
\end{tabular}

approximation (RMSEA) was equal to 0.077, which is less than the recommended level of 0.05 . Thus, the model needs to be modified.

After improving the initial model according to the suggestions of GOF measures and modification indices (MI) - adding covariance error paths among variables or latent factors-the model showed a good fit, and all GOF measures satisfied the recommended levels. For example, the values for GFI were higher than 0.9 , and those for AGFI were greater than 0.8 , thereby indicating the acceptable fit between the measurement model and raw data. The RMSEA value of 0.046 , which is less than 0.5 , implies that the modified model is acceptable at a certain confidence level. Additionally, all the relative indexes of IFI, TLI, and CFI were above 0.9 , thus providing strong evidence for the acceptable fit between the measurement model and data $[82,83]$. In summary, the GOF measures of the modified model demonstrated a successful fit between the measurement model and raw data (Table 6). Figure 3 shows the modified measurement model with standardized coefficients and factor loadings. Table 7 presents the standardized 
TABLE 5: Cronbach's alpha.

\begin{tabular}{lccccc}
\hline & $\begin{array}{c}\text { Economic } \\
\text { sustainability }\end{array}$ & $\begin{array}{c}\text { Social } \\
\text { sustainability }\end{array}$ & $\begin{array}{c}\text { Resource and environment } \\
\text { sustainability }\end{array}$ & $\begin{array}{c}\text { Engineering } \\
\text { sustainability }\end{array}$ & $\begin{array}{c}\text { Project management } \\
\text { sustainability }\end{array}$ \\
\hline Cronbach's alpha & 0.704 & 0.764 & 0.854 & 0.885 & 0.839 \\
\hline
\end{tabular}

regression weights and covariance estimates for the modified measurement model with the corresponding standard effort of estimates and $p$ values. All the standardized path coefficients for regression weights and covariance are highly positive and are significant at the 0.001 level (Table 7), implying that all the regression weights and covariance are significant.

5.5. Weights for Indicators. The weight of an indicator reflects its importance in the whole indicator system. This importance can be demonstrated by measuring the path coefficient values in the model. A higher path coefficient indicates the greater effect of the observed variable on the potential variable, because its factor has the highest level of characteristics [84]. Due to the different influences of each variable, the indicator weight of project sustainability can be obtained according to the value of the path coefficient. For example, $\mathrm{q}_{\mathrm{Eco} 1}$, the weight of indicator Ecol of the economic dimension, can be calculated by the following equation:

$$
q_{\mathrm{Eco} 1}=\frac{W_{\mathrm{Eco} 1}}{W_{\mathrm{Eco} 1}+W_{\mathrm{Eco} 2}+W_{\mathrm{Eco} 3}+W_{\mathrm{Eco} 4}+W_{\mathrm{Eco} 6}} .
$$

where $W_{\text {Ecol }}$ refers to the path coefficient value of Ecol in the measurement model.

The weights of other indicators can be obtained similarly.

Figure 3 shows that sustainable cash flow features the highest path coefficient of the economic variable, thereby indicating that this variable presents the most significant influence on economic sustainability. Therefore, the weight of this variable would also be the highest. Consequently, the path coefficient is applied to equation (1) to calculate the weight and rank each indicator. Table 8 shows the final sustainability evaluation indicator system of water environmental treatment PPP projects and the corresponding weight and ranking.

\section{Discussion}

Through the study of factors affecting the sustainability of water environment treatment PPP projects, 27 factors were identified. These factors were extracted in five categories, namely, economic sustainability, social sustainability, resource and environment sustainability, engineering sustainability, and project management sustainability. Combined with the indicator weight and ranking calculated in Section 5.3, the indicators of each dimension can be discussed as follows.

The economic sustainability dimension includes five indicators. The indicator "sustainable cash flow" is ranked as the most important indicator. If the project lacks cash flow, the financial resources needed in construction and operation cannot be guaranteed, and such condition is not conducive
TABLE 6: GOF measures of the modified measurement model.

\begin{tabular}{lcccc}
\hline Index name & $\begin{array}{c}\text { GOF } \\
\text { measures }\end{array}$ & Refined & $\begin{array}{c}\text { Recommended } \\
\text { levels }\end{array}$ & Evaluation \\
\hline \multirow{4}{*}{ Absolute fit } & $\chi^{2} / d f$ & 1.383 & $1-3$ & Acceptable \\
index & RMSEA & 0.046 & $<0.05$ & Acceptable \\
& RMR & 0.039 & $<0.05$ & Acceptable \\
& GFI & 0.915 & $>0.90$ & Acceptable \\
Incremental fit & AGFI & 0.867 & $>0.80$ & Acceptable \\
index & NFI & 0.766 & $>0.70$ & Acceptable \\
& TLI & 0.922 & $>0.90$ & Acceptable \\
& CFI & 0.906 & $>0.90$ & Acceptable \\
Parsimonious & PNFI & 0.655 & $>0.90$ & Acceptable \\
fit measure & PGNI & 0.647 & $>0.5$ & Acceptable \\
& PCFI & 0.786 & $>0.5$ & Acceptable \\
& & & & Acceptable \\
\hline
\end{tabular}

to the continuous operation of the project. Other indicators include "life-cycle cost," "internal return ratio (IRR)," "land value-added benefit around the project," and "fiscal pressures of government." To achieve economic sustainability in water environment treatment public-private partnership projects, we should shift their emphasis from first costs to life-cycle costs, where price of materials should account for costs such as emission, pollution, and waste [85]. IRR is one of the important indicators for evaluating the benefits of investment projects. A higher IRR indicates stronger project profitability. The private sector aims to achieve maximum IRR, but the public sector cannot accept higher IRR. Thus, the IRR should be at a reasonable level. Furthermore, treatment of water pollution areas can increase the value of lands around the project and promote regional economic development [1]. In China, the Ministry of Finance stipulates that the total expenditure of PPP projects per year cannot exceed $10 \%$ of the general public's budget. For the government, balancing the relationship between short-term and long-term development and formulating a long-term plan for fiscal expenditure is necessary. In addition, before the private sectors decide to invest in PPP projects, they need to consider the government's financial payment capacity. If the payment risk of the government is relatively high, the project may not achieve economic sustainability.

The social sustainability dimension includes three indicators. The indicator "public satisfaction" is ranked the most important in this group. The public represents an important stakeholder who is the most direct beneficiary and perceiver of water environment treatment PPP projects and whose satisfaction should be considered a crucial part of a performance evaluation system to achieve social sustainability development [86]. Other indicators in the social dimension include "provision of employment opportunities" and "potential impact on social development." These indicators exhibit a significant influence on promoting social sustainability because in project implementation, they can 


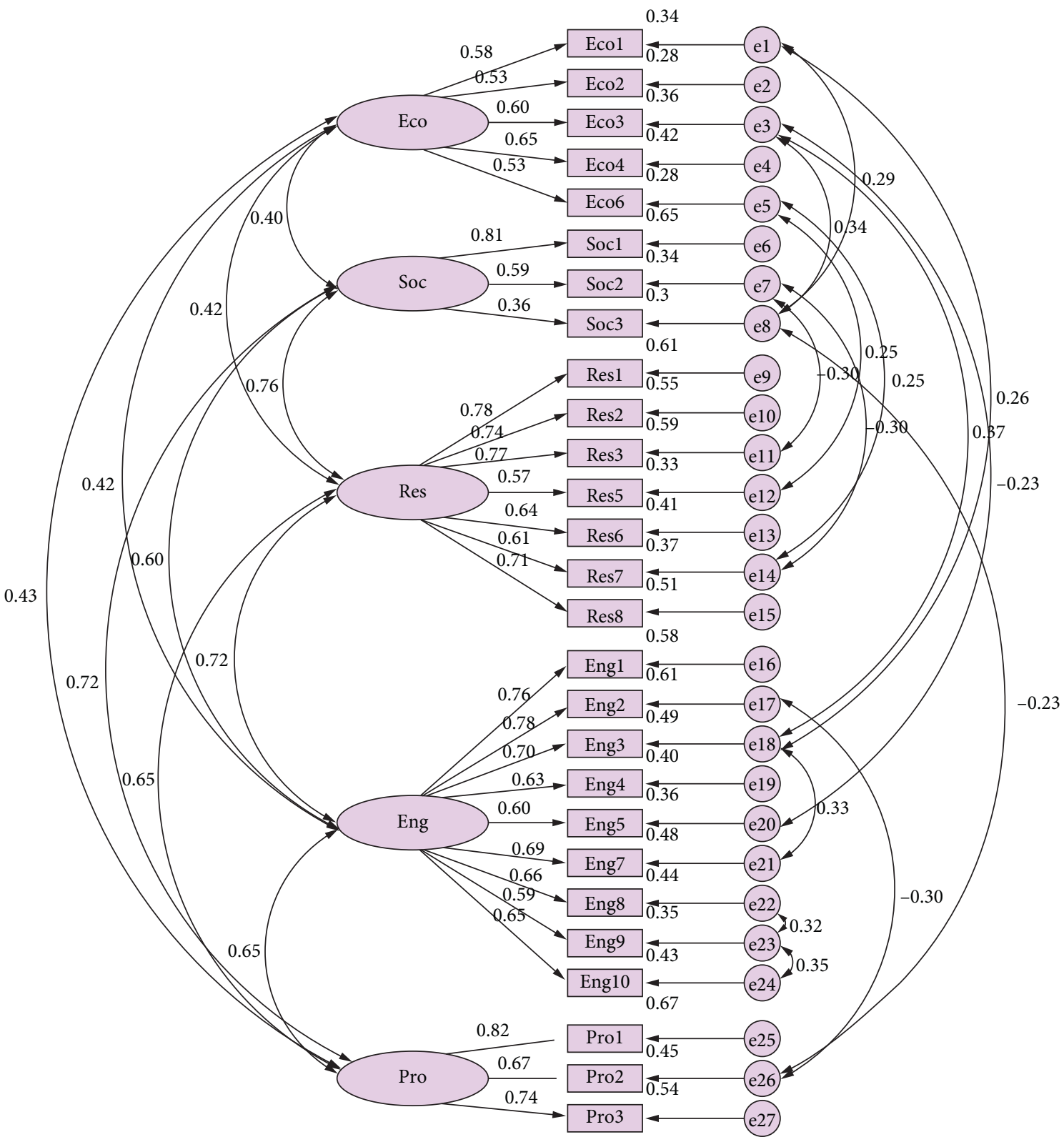

FIGURE 3: The modified measurement model with standardized path coefficients and factor loadings.

provide employment opportunities for vulnerable groups in society (such as those with low education, laid-off workers, and farmers) to fulfill food and clothing needs. Such a project can also improve people's living environment and promote the development of local tourism.

The resource and environment sustainability dimension includes seven indicators. The indicators of "effect on water quality" and "energy efficiency" rank first and second, respectively. For water environment treatment PPP projects, the most direct performance of the treatment is water quality, which is also the key to the sustainability of the whole project. People require extensive infrastructure for sustaining their lives. These facilities cause environmental problems during their construction, operation, and maintenance. They also consume substantial energy and natural resource. Therefore, the indicator of energy efficiency is crucial for project sustainability, because measures, such as reducing energy consumption and using renewable energy, can reduce greenhouse gas emissions, improve air quality, and build environment-friendly projects. Other indicators in the resource and environmental dimension include "reduction of pollutant discharge," "use of innovative materials," "sewage treatment rate," "comprehensive utilization of water resources," and "protection for landscape and historical sites."

The engineering sustainability dimension includes nine indicators, namely, "Completeness of supporting facilities for the project," "Renewal of project facilities," "Construction quality," "Control of pollution sources," "Adoption of advanced engineering technology," "Sustainability of the technology itself," "Capabilities of operation and maintenance," "Utilization of construction waste," and "Waste 
TABLE 7: The standardized regression weights and covariance estimates of the modified measurement model.

\begin{tabular}{|c|c|c|c|c|c|c|}
\hline & & & Estimate & S.E. & C.R. & $p$ \\
\hline Eco1 & $<---$ & Eco & 0.585 & & & \\
\hline Eco2 & $<---$ & Eco & 0.526 & 0.208 & 4.396 & $* * *$ \\
\hline Eco3 & $<---$ & Eco & 0.602 & 0.229 & 4.690 & $* * *$ \\
\hline Eco4 & $<---$ & Eco & 0.646 & 0.206 & 4.993 & $* * *$ \\
\hline Eco6 & $<---$ & Eco & 0.527 & 0.224 & 4.498 & $* * *$ \\
\hline Soc1 & $<---$ & Soc & 0.805 & & & \\
\hline Soc2 & $<---$ & Soc & 0.587 & 0.112 & 5.719 & $* * *$ \\
\hline Soc3 & $<---$ & Soc & 0.356 & 0.111 & 3.727 & $* * *$ \\
\hline Res1 & $<---$ & Res & 0.782 & & & \\
\hline Res2 & $<---$ & Res & 0.741 & 0.105 & 8.565 & $* * *$ \\
\hline Res3 & $<---$ & Res & 0.768 & 0.123 & 8.899 & $* * *$ \\
\hline Res5 & $<---$ & Res & 0.573 & 0.107 & 6.465 & $* * *$ \\
\hline Res6 & $<---$ & Res & 0.640 & 0.122 & 7.224 & $* * *$ \\
\hline Res7 & $<---$ & Res & 0.608 & 0.090 & 6.894 & $* * *$ \\
\hline Res8 & $<---$ & Res & 0.715 & 0.099 & 8.203 & $* * *$ \\
\hline Eng1 & $<---$ & Eng & 0.764 & & & \\
\hline Eng2 & $<---$ & Eng & 0.782 & 0.103 & 8.843 & $* * *$ \\
\hline Eng3 & $<---$ & Eng & 0.700 & 0.108 & 7.976 & $* * *$ \\
\hline Eng4 & $<---$ & Eng & 0.634 & 0.107 & 6.976 & $* * *$ \\
\hline Eng5 & $<---$ & Eng & 0.604 & 0.124 & 6.691 & $* * *$ \\
\hline Eng7 & $<---$ & Eng & 0.692 & 0.116 & 7.657 & $* * *$ \\
\hline Eng8 & $<---$ & Eng & 0.660 & 0.110 & 7.291 & $* * *$ \\
\hline Eng9 & $<---$ & Eng & 0.591 & 0.115 & 6.441 & $* * *$ \\
\hline Eng10 & $<---$ & Eng & 0.652 & 0.115 & 7.198 & $* * *$ \\
\hline Pro1 & $<---$ & Pro & 0.820 & & & \\
\hline Pro2 & $<---$ & Pro & 0.671 & 0.115 & 7.275 & $* * *$ \\
\hline Pro3 & $<---$ & Pro & 0.738 & 0.124 & 8.015 & $* * *$ \\
\hline
\end{tabular}

${ }^{* * *}$ The standardized regression weights and the covariance are significantly different from 0 at the 0.001 level (two-tailed).

recycling and reuse." Among them, "renewal of project facilities" is ranked as the most important indicator. Project facilities are easy to maintain and replace which will reduce operating costs and improve management efficiency. Therefore, the appropriate project facility renewal capability can extend service time and effectively improve operational efficiency to enhance the sustainability of a project [13]. For water environment treatment PPP projects, supporting facilities play an important role in maintaining daily construction and smooth operation. Project quality is the premise and guarantee of engineering sustainability. Corrosion of reinforcing steel in reinforced concrete structures has caused deterioration and damage that require repairs and maintenance to extend their service life $[87,88]$. In China, accidents such as bridge collapse or supply water pollution caused by the insufficient maintenance of infrastructure are common and have led to various social and environmental problems [10]. Therefore, the operational and maintenance capacity also play an important role in ensuring engineering sustainability. A sustainable water environment treatment PPP project not only requires that the treatment technology itself be sustainable but must also preclude damage to the natural environment. For example, in the early stage of water restoration, micro-nano aeration technology can increase dissolved oxygen in the water and provide a suitable living environment for submerged plants, emergent plants, and beneficial microorganisms. Furthermore, the complex microbial community can restore the
TABLE 8: Weight of the indicators.

\begin{tabular}{|c|c|c|c|}
\hline Dimension & Indicators & $\begin{array}{l}\text { Indicators } \\
\text { weights }\end{array}$ & Rank \\
\hline \multirow{5}{*}{ Economic } & Internal return ratio (IRR) & 0.203 & 3 \\
\hline & $\begin{array}{l}\text { Land value-added benefit } \\
\text { around the project }\end{array}$ & 0.182 & 5 \\
\hline & Life-cycle cost & 0.209 & 2 \\
\hline & Sustainable cash flow & 0.224 & 1 \\
\hline & Fiscal pressures of government & 0.183 & 4 \\
\hline \multirow{3}{*}{ Social } & Public satisfaction & 0.461 & 1 \\
\hline & $\begin{array}{c}\text { Provision of employment } \\
\text { opportunities }\end{array}$ & 0.336 & 2 \\
\hline & $\begin{array}{c}\text { Potential impact on } \\
\text { social development }\end{array}$ & 0.204 & 3 \\
\hline \multirow{7}{*}{$\begin{array}{l}\text { Resource } \\
\text { and } \\
\text { environment }\end{array}$} & Effect on water quality & 0.162 & 1 \\
\hline & $\begin{array}{l}\text { Reduction of } \\
\text { pollutant discharge }\end{array}$ & 0.154 & 3 \\
\hline & $\begin{array}{l}\text { Energy efficiency (e.g., } \\
\text { reduction of energy } \\
\text { consumption and use of } \\
\text { renewable energy resources) }\end{array}$ & 0.159 & 2 \\
\hline & $\begin{array}{l}\text { Protection for landscape and } \\
\text { historical sites }\end{array}$ & 0.119 & 7 \\
\hline & Sewage treatment rate & 0.133 & 5 \\
\hline & $\begin{array}{c}\text { Comprehensive utilization of } \\
\text { water resources }\end{array}$ & 0.126 & 6 \\
\hline & Use of innovation materials & 0.148 & 4 \\
\hline \multirow{9}{*}{ Engineering } & $\begin{array}{l}\text { Completeness of supporting } \\
\text { facilities for the project }\end{array}$ & 0.126 & 2 \\
\hline & Renewal of project facilities & 0.129 & 1 \\
\hline & Construction quality & 0.115 & 3 \\
\hline & Control of pollution sources & 0.104 & 7 \\
\hline & $\begin{array}{l}\text { Adoption of advanced } \\
\text { engineering technology }\end{array}$ & 0.099 & 8 \\
\hline & $\begin{array}{l}\text { Sustainability of the } \\
\text { technology itself }\end{array}$ & 0.114 & 4 \\
\hline & $\begin{array}{l}\text { Capabilities of operation } \\
\text { and maintenance }\end{array}$ & 0.109 & 5 \\
\hline & $\begin{array}{l}\text { Utilization of } \\
\text { construction waste }\end{array}$ & 0.097 & 9 \\
\hline & Waste recycling and reuse & 0.107 & 6 \\
\hline \multirow{3}{*}{$\begin{array}{l}\text { Project } \\
\text { management }\end{array}$} & Organization structure & 0.368 & 1 \\
\hline & $\begin{array}{l}\text { Continual improvement of the } \\
\text { operation management system }\end{array}$ & 0.301 & 3 \\
\hline & $\begin{array}{l}\text { Competence and skills of the } \\
\text { project team }\end{array}$ & 0.331 & 2 \\
\hline
\end{tabular}

self-purification (assimilative) capacity of water bodies through its own functional activities of digestion, decomposing, and metabolism. During construction, the project itself would also generate various construction wastes. For example, waste concrete can be crushed and sieved to fabricate recycled aggregates, which can then be produced into recycled concrete or recycled permeable concrete and finally be used in the project to realize construction waste recycling.

The project management sustainability dimension includes three indicators. The indicator "organization structure" is ranked as the most important in this group. The organization structure of a project can affect resource availability and project execution, which bears significance 
to sustainable project management. Water environment treatment PPP projects involve a long operation, a wide range, and numerous stakeholders. Thus, the organization structure should change with different concessionary stages. Furthermore, a stable project organization structure and effective communication are needed to ensure a continuous and healthy project operation. Human resource management factors contribute more to project sustainability than technical factors [43]. Project sustainability is limited in the early stage of management, because the concept of sustainable development has not been widely accepted. Therefore, all positive measures should be considered to improve the quality of project management personnel through various forms of learning and training. Furthermore, application of the PDCA cycle theory in the construction of a project management system can improve the scientific management level and work efficiency, reduce the project management cost, and promote the sustainable and healthy development of a project.

\section{Conclusions and Implications}

7.1. Conclusions. With the rapid development of economy and society, the problem of water environment pollution in China increases in severity. National attention to water pollution has resulted in a growing number of water environment treatment PPP projects, which should be evaluated in relation to sustainability for the healthy development of the projects. The idea of integrating sustainability into infrastructure projects has received widespread attention. Identifying factors that affect water environmental treatment PPP projects sustainability is an important issue that can lead to more sustainable infrastructures. Past research on sustainability evaluation of water environmental treatment PPP projects is relatively limited and based on the triple bottom line of economy, society, and environment, thereby lacking a more comprehensive evaluation index system. This paper connects these gaps by exploring the factors affecting project sustainability from five aspects: economy, society, resources and environment, engineering, and project management.

To ascertain the factors that influence the sustainability of water environment treatment PPP projects, a sustainability evaluation indicator system was initially constructed. A questionnaire survey was used to collect the opinions regarding the importance of sustainability indicators of projects. EFA was performed using SPSS to extract potential factors in the five dimensions mentioned, achieving a total of 27 influencing factors. Then, fitting degree analysis of the sample data and the model constructed by AMOS 22.0 was performed. The results showed that the modified model and original data were successfully fitted. Finally, index weight was calculated by path coefficient in the measuring model to ascertain the most important index in the different dimensions of project sustainability. The most important indicators in the five dimensions include economy (sustainable cash flow), society (public satisfaction), resources and environment (effect on water quality), engineering (renewal of project facilities), and project management (structure of management organization).

Traditional evaluation indexes come directly from literatures, and the quantity of literatures will affect the construction of the evaluation index system; so, it has certain randomness and uncertainty. On the basis of literature collection, the index system constructed in this paper considered the experience and knowledge of experts, screened the index through SPSS exploratory factor analysis, and carried out fitting degree analysis on the model constructed by AMOS to ensure the reliability of the index system.

7.2. Practical Implications. This study applied SEM method to provide a new perspective on the identification factors, affecting the sustainability for water environment treatment public-private partnership projects. The indicators have the most significant impact on project sustainability in the five dimensions, which provide a useful reference for the public and private sector to take appropriate measures to improve the sustainability level of water environment treatment public-private partnership projects. The research results provide a good reference for the public sector to conduct a new sustainability project decision-making, issue a sustainability regulation rule, and review a sustainability design plan. The private sector can easily find a solution to develop a sustainability water environment treatment project from all the perspective of economy, society, resources and environment, engineering, and project management. In summary, this research can be seen as a step up to have a holistic viewpoint in assessments of the sustainability of PPP projects focused on water environment treatment. The adopted approach and the results can be a stimulus for further studies to consider the effects of economic, social, resource and environment, engineering and project management dimensions on each other. The research method adopted in this paper has been applied in the procurement, decisionmaking, and operation management of water environment treatment PPP project in Xuchang City, China.

7.3. Limitations and Future Work. This paper provides two contributions: first, it identifies the sustainability indicators from five aspects in water environment treatment PPP projects. Second, this paper describes a methodology for evaluating and ranking factors and assesses the indicators featuring the most significant impact on project sustainability. This paper also has some limitations. Firstly, since sustainable development is a dynamic process which passes in time and depends on numerous parameters, there is no coincident conception of sustainability, and the indicators were not unambiguously qualified. There are differences between different types of PPP projects in different regions, so it is inappropriate to establish a universal indicator system. The index system established in this paper can provide a new comprehensive perspective for the sustainability evaluation of water environment treatment PPP projects, while it cannot be directly applied to other types of PPP projects. Therefore, in future studies, it is necessary to 
explore the sustainability evaluation index system and methods, and balance the completeness, adaptability, and the simplicity of operation of sustainable coverage, so that the system can be applied to other PPP projects. In addition, in the questionnaire survey process, the evaluation results of the importance of indicators largely depend on the experience of experts, which is highly subjective. Finally, the number of samples used in the survey is small, and increasing the sample size can result in achievements of more credible findings.

\section{Data Availability}

The data used to support the findings of this study are available from the corresponding author upon request.

\section{Conflicts of Interest}

The authors declare that there are no conflicts of interest regarding the publication of this paper.

\section{Acknowledgments}

This study was supported by the National Key R\&D Program of China (no. 2018YFC0406905), MOE (Ministry of Education in China) Project of Humanities and Social Sciences (no. 19YJC630078), National Natural Science Foundation of China (\#Project no. 71302191), the Foundation for Distinguished Young Talents in Higher Education of Henan (Humanities and Social Sciences) (no. 2017-cxrc-023), Training Program for Young Backbone Teachers in Institutions of Higher Learning of Henan (no. 2018GGJS080), and the 10th graduate student innovation project of North China University of Water Resources and Electric Power (no. YK2018-04).

\section{References}

[1] X. An, H. Li, L. Wang, Z. Wang, J. Ding, and Y. Cao, "Compensation mechanism for urban water environment treatment PPP project in China," Journal of Cleaner Production, vol. 201, pp. 246-253, 2018.

[2] Y. Ke, "Is public-private partnership a panacea for infrastructure development? The case of Beijing National Stadium," International Journal of Construction Management, vol. 14, no. 2, pp. 90-100, 2014.

[3] B.-G. Hwang, X. Zhao, and M. J. S. Gay, "Public private partnership projects in Singapore: factors, critical risks and preferred risk allocation from the perspective of contractors," International Journal of Project Management, vol. 31, no. 3, pp. 424-433, 2013.

[4] L. Tang, Q. Shen, and E. W. L. Cheng, "A review of studies on public-private partnership projects in the construction industry," International Journal of Project Management, vol. 28, no. 7, pp. 683-694, 2010.

[5] E. G. Satolo and A. T. Simon, "Critical analysis of assessment methodologies for intraorganizational sustainability," Management of Environmental Quality: An International Journal, vol. 26, no. 2, pp. 214-232, 2015.

[6] S. Lenferink, T. Tillema, and J. Arts, "Towards sustainable infrastructure development through integrated contracts: experiences with inclusiveness in Dutch infrastructure projects," International Journal of Project Management, vol. 31, no. 4, pp. 615-627, 2013.

[7] M. Hueskes, K. Verhoest, and T. Block, "Governing public-private partnerships for sustainability: an analysis of procurement and governance practices of PPP infrastructure projects," International Journal of Project Management, vol. 35, no. 6, pp. 1184-1195, 2017.

[8] J. S. Timmermans and G. E. G. Beroggi, "Conflict resolution in sustainable infrastructure management," Safety Science, vol. 35, no. 1-3, pp. 175-192, 2000.

[9] H. R. Sahely, C. A. Kennedy, and B. J. Adams, "Developing sustainability criteria for urban infrastructure systems," $\mathrm{Ca}$ nadian Journal of Civil Engineering, vol. 32, no. 1, pp. 72-85, 2005.

[10] L. Shen, Y. Wu, and X. Zhang, "Key assessment indicators for the sustainability of infrastructure projects," Journal of Construction Engineering and Management, vol. 137, no. 6, pp. 441-451, 2011.

[11] M. Martinsuo and P. Lehtonen, "Role of single-project management in achieving portfolio management efficiency," International Journal of Project Management, vol. 25, no. 1, pp. 56-65, 2007.

[12] A. Nieminen and M. Lehtonen, "Organisational control in programme teams: an empirical study in change programme context," International Journal of Project Management, vol. 26, no. 1, pp. 63-72, 2008.

[13] J. Kivilä, M. Martinsuo, and L. Vuorinen, "Sustainable project management through project control in infrastructure projects," International Journal of Project Management, vol. 35, no. 6, pp. 1167-1183, 2017.

[14] D. E. Armanios, "Sustainable development as a community of practice: insights from rural water projects in Egypt," Sustainable Development, vol. 20, no. 1, pp. 42-57, 2012.

[15] L. Gan, L. Shen, and H. Fu, "Study of infrastructure project evaluation factors based on sustainable development," China Civil Engineering Journal, vol. 42, no. 11, pp. 133-138, 2009.

[16] L. Shen, H. Li, and Q. M. Li, "Alternative concession model for build operate transfer contract projects," Journal of Construction Engineering and Management, vol. 131, pp. 211-220, 2002.

[17] S. Dasgupta and E. K. L. Tam, "Indicators and framework for assessing sustainable infrastructure," Canadian Journal of Civil Engineering, vol. 32, no. 1, pp. 30-44, 2005.

[18] O. O. Ugwu, M. M. Kumaraswamy, A. Wong, and S. T. Ng, "Sustainability appraisal in infrastructure projects (SUSAIP)," Automation in Construction, vol. 15, no. 2, pp. 239-251, 2006.

[19] A. Amiril, A. H. Nawawi, R. Takim, and S. N. F. A. Latif, "Transportation infrastructure project sustainability factors and performance," Procedia-Social and Behavioral Sciences, vol. 153, pp. 90-98, 2014.

[20] E. Cheung, A. P. C. Chan, P. T. I. Lam, D. W. M. Chan, and Y. Ke, "A comparative study of critical success factors for public private partnerships (PPP) between Mainland China and the Hong Kong Special Administrative Region," Facilities, vol. 30, no. 13-14, pp. 647-666, 2012.

[21] N. A. Patil, D. Tharun, and B. Laishram, "Infrastructure development through PPPs in India: criteria for sustainability assessment," Journal of Environmental Planning and Management, vol. 59, no. 4, 2016.

[22] A. P. C. Chan, P. T. I. Lam, Y. Wen et al., "Cross-sectional analysis of critical risk factors for PPP water projects in China," Journal of Infrastructure Systems, vol. 21, no. 1, p. 10, 2015.

[23] Y. Ke, S. Wang, and A. P. C. Chan, "Risk management practice in China's public-private partnership projects," Journal of 
Civil Engineering and Management, vol. 18, no. 5, pp. 675684, 2012.

[24] R. Osei-Kyei and A. P. C. Chan, "Review of studies on the critical success factors for public-private partnership (PPP) projects from 1990 to 2013," International Journal of Project Management, vol. 33, no. 6, pp. 1335-1346, 2015.

[25] L. Shen, V. W. Y. Tam, L. Gan et al., "Improving sustainability performance for public-private-partnership (PPP) projects," Sustainability, vol. 8, no. 3, p. 15, 2016.

[26] N. A. Patil and B. Laishram, "Public-private partnerships from sustainability perspective-a critical analysis of the Indian case," International Journal of Construction Management, vol. 16, no. 2, pp. 161-174, 2016.

[27] J. F. M. Koppenjan and B. Enserink, "Public-private partnerships in urban infrastructures: reconciling private sector participation and sustainability," Public Administration Review, vol. 69, pp. 284-296, 2010.

[28] X. Ye and Y. Deng, "Research on the approach to realize sustainability of PPP infrastructure project from the perspective of partnership," Proceedings of Science and Technology Management Research, vol. 34, no. 12, pp. 189-193, 2014.

[29] A. M. Al-Damkhi, S. A. Abdul-Wahab, and A. S. Al-Nafisi, "On the need to reconsider water management in Kuwait," Clean Technologies and Environmental Policy, vol. 11, no. 4, pp. 379-384, 2009.

[30] J. Almedeij, "The future sustainability of water supply in Kuwait," Water International, vol. 32, pp. 604-617, 2007.

[31] J. C. Elnaboulsi, "An efficient pollution control instrument: the case of urban wastewater pollution," Environmental Modeling \& Assessment, vol. 16, no. 4, pp. 343-358, 2011.

[32] S. Zanni, S. S. Cipolla, E. D. Fusco et al., "Modeling for sustainability: life cycle assessment application to evaluate environmental performance of water recycling solutions at the dwelling level," Sustainable Production and Consumption, vol. 17, pp. 47-61, 2019.

[33] F. Pellicer-Martínez and J. M. Martínez-Paz, "The water footprint as an indicator of environmental sustainability in water use at the river basin level," Science of the Total Environment, vol. 571, pp. 561-574, 2016.

[34] B. Nuong, A. Kawamura, H. Amaguchi et al., "Social sustainability assessment of groundwater resources: a case study of Hanoi, Vietnam," Ecological Indicators, vol. 93, pp. 10341042, 2018.

[35] T. Ramos and S. M. Pires, Sustainability Assessment: The Role of Indicators, Springer, Berlin, Germany, 2013.

[36] W. Xiong and D. Zhu, "Theory and practice of sustainability-oriented public private partnership," Journal of Tongji University, vol. 28, pp. 78-84, 2017.

[37] D. K. Chatterjee, "Review symposium: our common future: the world commission on environment and development," Australian Geographer, vol. 20, pp. 195-201, 1989.

[38] V. Mani, A. Gunasekaran, T. Papadopoulos, B. Hazen, and R. Dubey, "Supply chain social sustainability for developing nations: evidence from India," Resources, Conservation and Recycling, vol. 111, pp. 42-52, 2016.

[39] M. Yılmaz and A. Bakış, "Sustainability in construction sector," Procedia-Social and Behavioral Sciences, vol. 195, pp. 2253-2262, 2015.

[40] S. Vyas, S. Ahmed, and A. Parashar, "BEE (bureau of energy efficiency) and green buildings," Berichte Der Deutschen Chemischen Gesellschaft, vol. 58, pp. 23-32, 2014.

[41] R. P. J. Schipper and A. J. G. Silvius, "Sustainability in project management: a literature review and impact analysis," Social Business, vol. 4, no. 1, pp. 63-96, 2014.
[42] M. M. Carvalho, "An investigation of the role of communication in IT projects," International Journal of Operations and Production Management, vol. 34, no. 1, pp. 36-64, 2014.

[43] C. Scott-Young and D. Samson, "Project success and project team management: evidence from capital projects in the process industries," Journal of Operations Management, vol. 26, no. 6, pp. 749-766, 2008.

[44] L.-y. Shen, V. W. Y. Tam, L. Tam, and Y.-b. Ji, "Project feasibility study: the key to successful implementation of sustainable and socially responsible construction management practice," Journal of Cleaner Production, vol. 18, no. 3, pp. 254-259, 2010.

[45] L.-Y. Shen, J. L. Hao, V. W.-Y. Tam, and H. Yao, “A checklist for assessing sustainability performance of construction projects," Journal of Civil Engineering and Management, vol. 13, no. 4, pp. 273-281, 2007.

[46] G. Fernández-Sánchez and F. Rodríguez-López, "A methodology to identify sustainability indicators in construction project management-application to infrastructure projects in Spain," Ecological Indicators, vol. 10, no. 6, pp. 1193-1201, 2010.

[47] R. K. Mavi and C. Standing, "Critical success factors of sustainable project management in construction: a fuzzy DEMATEL-ANP approach," Journal of Cleaner Production, vol. 194, pp. 751-765, 2018.

[48] G. Heravi, M. Fathi, and S. Faeghi, "Evaluation of sustainability indicators of industrial buildings focused on petrochemical projects," Journal of Cleaner Production, vol. 109, pp. 92-107, 2015.

[49] H. Alwaer, M. Sibley, and J. Lewis, "Factors and priorities for assessing sustainability of regional shopping centres in the UK," Architectural Science Review, vol. 51, no. 4, pp. 391-402, 2008.

[50] C. S. Ko, E. Y. Shon, and J. E. Jeong, "A comparative analysis on implementation methods of road PPP project*-a case study of incheon international airport expressway project," Seoul Studies, vol. 18, pp. 41-51, 2017.

[51] Y. Wang and Z. J. Zhao, "Motivations, obstacles, and resources," Public Performance \& Management Review, vol. 37, no. 4, pp. 679-704, 2014.

[52] J. P. Walters and A. N. Javernick-Will, "Long-term functionality of rural water services in developing countries: a system dynamics approach to understanding the dynamic interaction of factors," Environmental Science \& Technology, vol. 49, no. 8, pp. 5035-5043, 2015.

[53] V. Klevas, D. Streimikiene, and A. Kleviene, "Sustainability assessment of the energy projects implementation in regional scale," Renewable and Sustainable Energy Reviews, vol. 13, no. 1, pp. 155-166, 2009.

[54] H. Alwaer, M. Sibley, and J. Lewis, "Different stakeholder perceptions of sustainability assessment," Architectural Science Review, vol. 51, no. 1, pp. 48-59, 2008.

[55] F. Boschetti, C. Cvitanovic, A. Fleming, and E. Fulton, "A call for empirically based guidelines for building trust among stakeholders in environmental sustainability projects," Sustainability Science, vol. 11, no. 5, pp. 855-859, 2016.

[56] S. G. Moon, S. Y. Jeong, and Y. Choi, "Moderating effects of trust on environmentally significant behavior in Korea," Sustainability, vol. 9, p. 19, 2017.

[57] P. Bynum, R. R. A. Issa, and S. Olbina, "Building information modeling in support of sustainable design and construction," Journal of Construction Engineering and Management, vol. 139, no. 1, pp. 24-34, 2013.

[58] L. B. Robichaud and V. S. Anantatmula, "Greening project management practices for sustainable construction," Journal of Management in Engineering, vol. 27, no. 1, pp. 48-57, 2011. 
[59] C.-P. Tung, T.-C. Lee, W.-T. Liao, and Y.-J. Chen, "Climate change impact assessment for sustainable water quality management," Terrestrial, Atmospheric and Oceanic Sciences, vol. 23, no. 5, pp. 565-576, 2012.

[60] S. Yu and H. Lu, "Integrated watershed management through multi-level and stepwise optimization for allocation of total load of water pollutants at large scales," Environmental Earth Sciences, vol. 77, no. 10, p. 13, 2018.

[61] O. O. Ugwu and T. C. Haupt, "Key performance indicators and assessment methods for infrastructure sustainability-a South African construction industry perspective," Building and Environment, vol. 42, no. 2, pp. 665-680, 2007.

[62] M. Lundin and G. M. Morrison, "A life cycle assessment based procedure for development of environmental sustainability indicators for urban water systems," Urban Water, vol. 4, no. 2, pp. 145-152, 2002.

[63] X. Wang, J. Liu, N.-Q. Ren, H.-Q. Yu, D.-J. Lee, and X. Guo, "Assessment of multiple sustainability demands for wastewater treatment alternatives: a refined evaluation scheme and case study," Environmental Science \& Technology, vol. 46, no. 10, pp. 5542-5549, 2012.

[64] A. J. Balkema, H. A. Preisig, R. Otterpohl, and F. J. D. Lambert, "Indicators for the sustainability assessment of wastewater treatment systems," Urban Water, vol. 4, no. 2, pp. 153-161, 2002.

[65] M. A. Brown and B. K. Sovacool, "Developing an 'energy sustainability index' to evaluate energy policy," Interdisciplinary Science Reviews, vol. 32, no. 4, pp. 335-349, 2007.

[66] J. Davis, H. Lukacs, M. Jeuland et al., "Sustaining the benefits of rural water supply investments: experience from Cochabamba and Chuquisaca, Bolivia," Water Resources Research, vol. 44, no. 12, 2008.

[67] D. Whittington, J. Davis, L. Prokopy et al., "How well is the demand-driven, community management model for rural water supply systems doing?" SSRN Electronic Journal, vol. 11, no. 2208, pp. 696-718, 2008.

[68] G. Cserháti and L. Szabó, "The relationship between success criteria and success factors in organisational event projects," International Journal of Project Management, vol. 32, no. 4, pp. 613-624, 2014.

[69] R. B. Kline, "Principles and practice of structural equation modeling," Journal of the American Statistical Association, vol. 101, 2011.

[70] F. D. F. Larcker, "Structural equation models with unobservable variables and measurement error: algebra and statistics," Journal of Marketing Research, vol. 18, pp. 39-50, 1981.

[71] B. Xiong, M. Skitmore, B. Xia, M. A. Masrom, K. Ye, and A. Bridge, "Examining the influence of participant performance factors on contractor satisfaction: a structural equation model," International Journal of Project Management, vol. 32, no. 3, pp. 482-491, 2014.

[72] R. Lomax, "Covariance structure analysis: extensions and development," Advance in Social Science Methodology, vol. 1, pp. 171-204, 1989.

[73] J. C. Loehlin, Latent Variable Model: An Introduction to Factor, Path, and Structural Analysis, CRC Press, Boca Raton, FL, USA, 1992.

[74] J. C. Anderson and D. W. Gerbing, "Structural equation modeling in practice: a review and recommended two-step approach," Psychological Bulletin, vol. 103, no. 3, pp. 411-423, 1988.

[75] H. H. Harman, Modern Factor Analysis, University of Chicago Press, Chicago, IL, USA, 1976.
[76] P. M. Podsakoff, S. B. Mackenzie, J.-Y. Lee, and N. P. Podsakoff, "Common method biases in behavioral research: a critical review of the literature and recommended remedies," Journal of Applied Psychology, vol. 88, no. 5, pp. 879-903, 2003.

[77] A. D. Beuckelaer and S. M. Wagner, "Small sample surveys: increasing rigor in supply chain management research," International Journal of Physical Distribution and Logistics Management, vol. 42, no. 7, pp. 615-639, 2012.

[78] J. S. Armstrong and T. S. Overton, "Estimating nonresponse bias in mail surveys," Journal of Marketing Research, vol. 14, no. 3, pp. 396-402, 1977.

[79] N. Blunch, "Introduction to structural equation modelling: using SPSS and AMOS," British Journal of Psychology, vol. 34, no. 3, pp. 211-213, 2019.

[80] J. Guan and N. Ma, "Structural equation model with PLS path modeling for an integrated system of publicly funded basic research," Scientometrics, vol. 81, no. 3, pp. 683-698, 2009.

[81] R. L. Matsueda, "Structural equations with latent Variables.Kenneth A. Bollen," American Journal of Sociology, vol. 96, no. 6, pp. 1553-1555, 1991.

[82] D. L. Jackson, J. A. Gillaspy, and R. Purc-Stephenson, "Reporting practices in confirmatory factor analysis: an overview and some recommendations," Psychological Methods, vol. 14, no. 1, pp. 6-23, 2009.

[83] J. Meng, B. Xue, B. Liu, and N. Fang, "Relationships between top managers' leadership and infrastructure sustainability," Engineering, Construction and Architectural Management, vol. 22, no. 6, pp. 692-714, 2015.

[84] L. Jiao, L. Shen, C. Shuai et al., "A novel approach for assessing the performance of sustainable urbanization based on structural equation modeling: a China case study," Sustainability, vol. 8, no. 9, p. 910, 2016.

[85] C. J. Kibert, Sustainable Construction: Green Building Design and Delivery, Wiley, Chichester, UK, Chichester, UK, 4th edition, 2016.

[86] W. Xiong, J.-F. Yuan, Q. Li, and M. J. Skibniewski, "Performance objective-based dynamic adjustment model to balance the stakeholders' satisfaction in PPP projects," Journal of Civil Engineering and Management, vol. 21, no. 5, pp. 539-547, 2015.

[87] Z. C. Gao, A. K. Patnaika, and R. Liang, "VIKOR method for ranking concrete bridge repair projects with target-based criteria," in Proceedings of Corrosion Risk Management Conference, pp. 175-192, Houston, TX, USA, 2016.

[88] Z. Gao and J. Li, "Fuzzy analytic hierarchy process evaluation method in assessing corrosion damage of reinforced concrete bridges," Civil Engineering Journal, vol. 4, no. 4, pp. 843-856, 2018. 


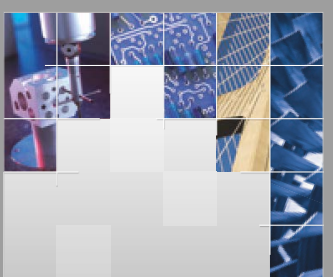

\section{Enfincering}
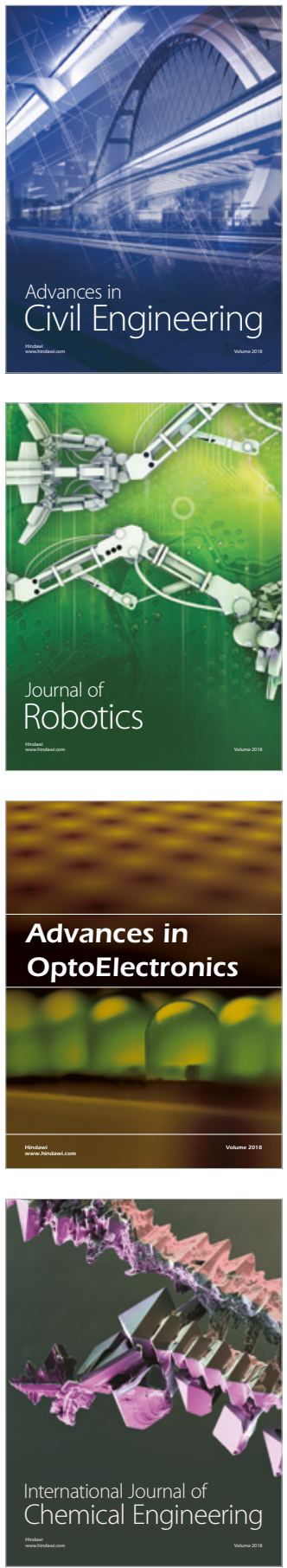

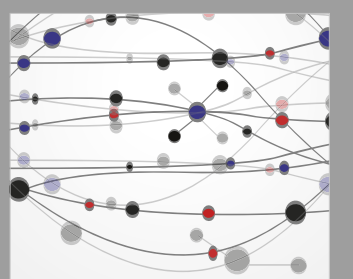

\section{Rotating \\ Machinery}

The Scientific World Journal

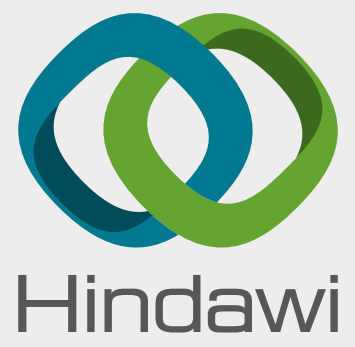

Submit your manuscripts at

www.hindawi.com
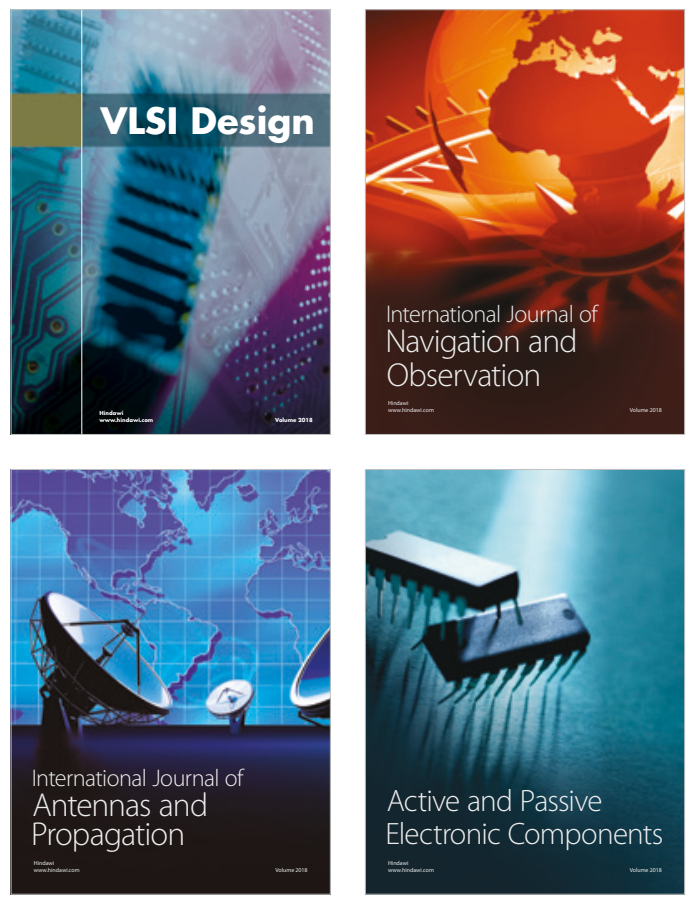
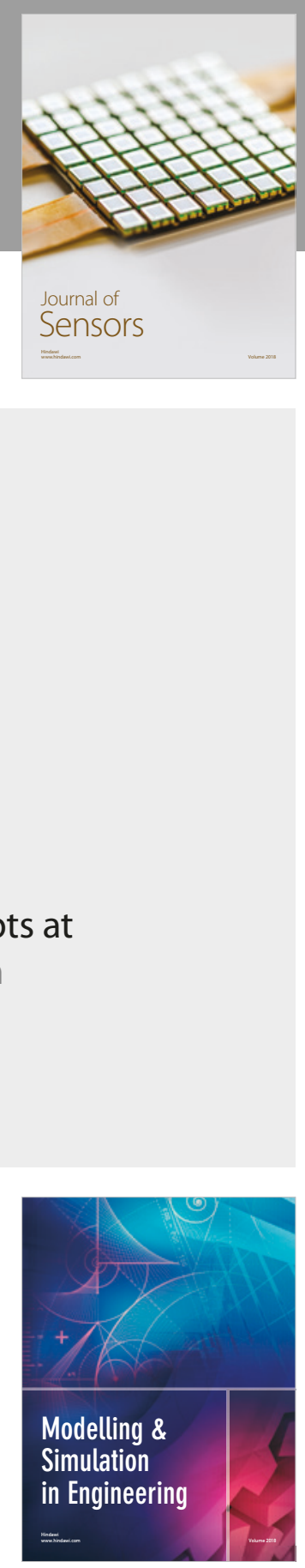

\section{Advances \\ Multimedia}
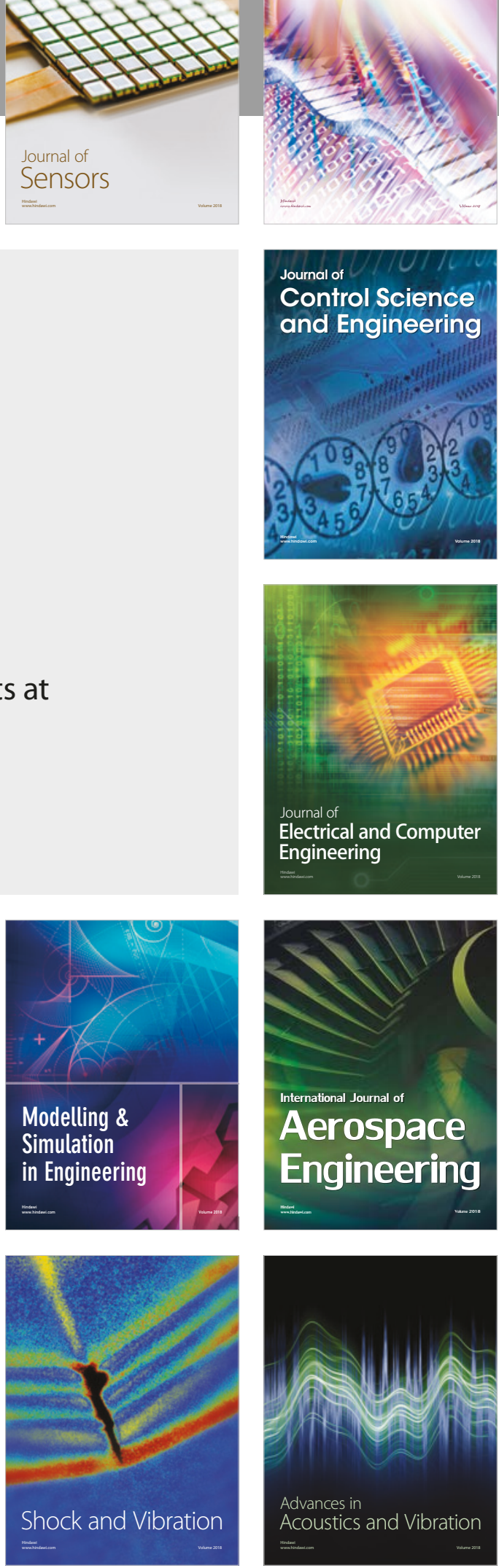